\title{
Imagens grotescas de corpo no Apocalipse de Pedro
}

\section{Grotesque body images in Peter's Apocalypse}

\section{Resu mo}

O presente artigo apresenta uma breve análise do texto apócrifo do Cristianismo Primitivo conhecido como Apocalipse de Pedro, em especial do trecho em que se observam condenações e castigos a condenados em sua descrição de inferno, à luz do que se designa como Teoria do Monstruoso. O texto expõe as motivações para a escolha da fonte, sua relevância para os estudos das origens do Cristianismo e, em seguida, apresenta trechos da obra, fazendo o recorte das descrições de condenações, além de procurar fazer uma leitura aberta, segundo discussões que tomam como referências a perspectiva de grotesco e desenvolvimentos desse conceito em outros desdobramentos a partir de Cohen e Asma, buscando a conceituação do que poderia ser chamado de Teoria do Monstruoso.

Palavras-chave: Apocalipse de Pedro. Inferno. Teoria do monstruoso.

\section{Abstract}

This article presents a brief analysis of the apocryphal text of Early Christianity known as the Apocalypse of Peter, in particular, the passage in which condemnations and punishments for the condemned are observed in its description of hell, in light of what we designate as the Monstrous Theory. The text exposes the motivations for choosing the source, its relevance to the studies of the origins of Christianity and then presents excerpts from the work, cutting out the descriptions of convictions and trying to make an open reading of the work, according to discussions that take as referential the perspective of grotesque and developments of this concept in other developments, from Cohen and Asma seeking the conceptualization of what could be called the Theory of the Monstrous.

Keywords: Peter's Apocalypse. Hell. Monstrous theory.

\section{I n t rod u ção}

Neste artigo buscar-se-á introduzir a fonte selecionada para a discussão, o Apocalipse de Pedro (ApPe), justificando sua escolha através da importância de se pesquisar textos apócrifos para a compreensão das origens do Cristianismo Primitivo (CP); selecionar os trechos que entende-se serem mais relevantes 
para o debate teórico e introduzir a Teoria do Monstruoso como método de leitura e interpretação da fonte. Em conjunto, buscar-se-á fazer ainda uma leitura aberta da obra evitando oferecer interpretações prontas, mas buscando justificar, já nas linhas conclusivas, a leitura e interpretação do ApPe feita pelo autor à luz da teoria, por ver essa perspectiva como adequada e desafiadora para a pesquisa dessa e de outras fontes das origens do movimento cristão.

\section{Porque o Apocalipsede Pedro (ApPe)}

O Apocalipse de Pedro foi escolhido por duas razões específicas: a primeira, por se tratar de uma das fontes mais antigas da apocalíptica cristã sobre o além-mundo. Pretende-se, a partir do esclarecimento do mundo dos mortos imaginado pelos cristãos dos primeiros séculos, acessar a maneira como o CP delimitou o espaço dos mortos em esferas razoavelmente controláveis. O trabalho sobre o Apocalipse de Pedro (ApPe) (Schneemelcher, 2003) é fundamentalmente importante pois, além de ser uma fonte muito antiga e pouco debatida, é nessa obra de referência de descrição do inferno cristão que se tem uma perspectiva mais "plástica" dos mortos condenados ao inferno. Ou seja, no ApPe os corpos dos mortos-condenados são dissecados e dilacerados em castigos que se aproximam de experimentos e a narrativa é construída no espectro desse imaginar dos corpos sendo castigados de forma monstruosa.

Optou-se por debater essa fonte porque as pesquisas sobre os escritos apócrifos dos últimos anos elaboradas especialmente no Brasil pelo Professor Doutor Paulo Nogueira com o Grupo Oracula de pesquisa têm dado evidências de que a forma mais generosa e adequada e de compreender as origens do cristianismo é evitar separar o mundo religioso, social e imaginativo romano do mundo religioso, social e imaginativo cristão ou mesmo judaico. É possível que seja mais enriquecedor para a pesquisa bíblica pensar que os mundos citados acima não são separados como algumas vertentes possam demonstrar, uma vez que o mundo em que nasce o cristianismo dentro dos limites do Império Romano, com relação direta com o Império e também em diálogo com o judaísmo, do qual ele só viria a se separar bastante tempo depois, porque se acredita ser a partir dessa base de relacionamentos, dessa fronteira cultural em que os primeiros cristãos caminham na história de suas origens, que se desenvolve o que é chamado de Cristianismo Primitivo.

\section{O Cristianismo Primitivo e construção de novas possibilidades de experimentar o mundo através de suas narrativas}

Em sua reflexão sobre a religião como uma forma secundária de linguagem, Nogueira argumenta que embora este seja um mundo de regras, ideologias, convenções sociais e divisões de classes estabelecidas, a partir de uma sociedade que as estabelece e, assim, ganhando um ar de universalidade, acabam por ser assumidas como realidade, se tornando valores e fazendo com que essas convenções sejam aceitas como modo de ver o mundo. A literatura exerce um poderoso papel de desconstrução (Nogueira, 2015). Segundo Iser (1975), esse seria o papel da ficção literária: modelizar, manipular, negar e inverter o mundo, que é constituído de discurso através de um segundo modelo de discurso e linguagem, e pode ser manipulado.

Assim, através de uma forte característica ficcional, o CP teria mapeado e construído um outro mundo possível. Essa é a hipótese considerada neste artigo: ao imaginar um além-mundo, o CP concebeu, 
através de um modo fantástico de narrar, uma nova realidade, manipulada através de sua literatura. O CP construiu suas narrativas de além para inverter uma realidade injusta e corrigir os cursos dessa realidade, levando um destino desejado aos seus opositores. O referencial teórico pretende analisar a partir desses pressupostos de um mundo além, da lógica invertida, da geografia própria e outras regras, como esse modo de narrar foi utilizado pelo CP em suas descrições de Inferno na fonte analisada a seguir.

\section{O Apocalipsede Pedro - breve apresentação e es boço}

Neste tópico, procurar-se-á fazer uma apresentação da fonte em linhas gerais e um esboço do todo da obra, uma vez que não caberia expor uma tradução. A intenção é fazê-la conhecida e recortar os trechos relevantes para a análise proposta.

O ApPe é um texto bastante antigo e, a julgar por citações de Clemente de Alexandria, pode ser originário ainda dos fins do segundo século. Como um apocalipse situado no final da história do evangelho de Jesus, o Apocalipse de Pedro é um exemplo de um gênero de apocalipse cristão que parece ter se tornado muito popular no segundo e terceiro séculos: o discurso revelador de Jesus a um ou mais discípulos ou o diálogo revelador de Jesus com os discípulos após a ressurreição. Como o Apocalipse de Pedro, essas obras são frequentemente narradas no monte das Oliveiras ou em alguma outra montanha. Além disso, eles frequentemente terminam com um relato da ascensão. Por outro lado, diferente do Apocalipse de Pedro, eles geralmente começam com um relato da aparição de Jesus ressuscitado aos discípulos. A esse respeito, o Apocalipse de Pedro é bastante peculiar. A maneira como a narrativa se abre torna improvável que um relato de uma aparição de Jesus no início do texto tenha sido perdido, mas significa que não há uma maneira clara de saber que o cenário é definido após a ressurreição até que se chegue ao relato da ascensão de Jesus, no final da obra (Bauckham, 1998).

O texto se inicia com uma reunião de Jesus com seus discípulos no Monte das Oliveiras. Ali, Jesus está anunciando o seu sermão apocalíptico, numa versão que procura ser semelhante à de Marcos 13:

\footnotetext{
E quando o Senhor estava sentado no Monte das Oliveiras, seus discípulos foram até ele. E nós suplicamos e rogamos e suplicamos-lhe separadamente e imploramos-lhe, dizendo-lhe: 'Declara-nos quais são os sinais da tua vinda e do fim do mundo, para que possamos perceber e marcar o tempo da tua vinda e instruir aqueles que vêm depois de nós, a quem pregamos a palavra do teu evangelho, e a quem instalamos na tua igreja, para que, quando o ouvirem, prestem atenção a si próprios e marquem o tempo da tua vinda'.

E nosso Senhor nos respondeu dizendo: 'Vede, que ninguém vos engane e que não duvidem e sirvam a outros deuses. Muitos virão em meu nome, dizendo: 'Eu sou o Cristo'. Não acredite neles, nem chegue perto deles. Pois a vinda do Filho de Deus não será clara; mas como o relâmpago que brilha de leste a oeste, eu virei sobre as nuvens do céu com um grande exército em minha majestade; com minha cruz indo diante de minha face, irei em minha majestade; brilhando sete vezes mais brilhante do que o sol virei em minha majestade com todos os meus santos, meus anjos. E meu Pai porá uma coroa sobre minha cabeça, para que eu possa julgar os vivos e os mortos e recompensar a cada um de acordo com suas obras' (Elliot, 1993, p. 600).
}

Apresentando uma visão em que Pedro é o narrador e, ao mesmo tempo, aquele que vê as cenas descritas, Elliot questiona se Jesus toma Pedro em uma jornada ao além ou se sua descrição é tão vívida e detalhada que dá a impressão de que Pedro realmente está vendo (Elliot, 1993). O texto afirma, entretanto, 
que Pedro vê o destino dos mortos na palma da mão direita de Jesus e descreve seus tormentos e as ações dos anjos que operam as ações de castigo dos condenados.

\section{Es b oço e conteúdo do ApPe}

O ApPe pode ser resumido a partir do seguinte esboço:

(a) Discurso sobre os sinais e o tempo da parusia:

I: 1-3 O inquérito dos discípulos

1: 4-8 A parusia será inconfundível

2: A parábola da figueira: o falso Messias e oss mártires dos últimos dias

(b) Visão do julgamento e sua explicação

3: Imagem do julgamento e a angústia de Pedro

4: A ressurreição

5: A conflagração cósmica

6: 1-6 O último julgamento

6: 7-9 O julgamento dos espíritos malignos

7-12 Os castigos no inferno

13: As punições confirmadas como justas

14: 1 As orações dos eleitos salvam alguns

14: 2-3 Os eleitos herdam as promessas

14: 4-6 O futuro terrestre de Pedro

(c) Visões da recompensa dos justos

15: Visão de Moisés e Elias

16: 1-6 Visão do Paraíso

16: 7-17: I Visão do verdadeiro templo e audição sobre o verdadeiro Messias

17: 2-7 A ascensão

Para alcançar o objetivo deste trabalho, a parte que importa mais detalhadamente é a extensa lista apresentada no ApPe de castigos sofridos no inferno. Jesus mostra a Pedro uma visão do julgamento de todas as pessoas no último dia. Pedro está angustiado com o destino dos pecadores, mas sua afirmação de que seria melhor eles não terem sido criados é rejeitada por Jesus, que promete mostrar a Pedro as ações dos pecadores (a fim de permitir que ele aprecie a justiça de suas condenações).

Uma longa profecia (feita por Jesus) do julgamento dos pecadores pode ser lida a seguir. Começa com um relato da ressurreição, que deve ocorrer para que toda a humanidade possa aparecer diante de Deus no dia do julgamento. A palavra de Deus reivindicará todos os mortos, inclusive os que foram devorados por feras e que serão devolvidos "porque para Deus nada é impossível". Então seguirá a conflagração cósmica, na qual uma inundação de fogo consumirá os céus e o mar e levará todas as pessoas a julgamento no rio de fogo. Depois Jesus Cristo virá e será entronizado e coroado como juiz. Todos serão julgados de acordo com suas ações. O rio de fogo pelo qual todos devem passar provará sua inocência ou culpa. Os anjos levarão os ímpios para o inferno. Os demônios também serão julgados e condenados ao castigo eterno. 


\section{A Tabela 1 apresenta uma longa descrição dos castigos no inferno. Um castigo específico e diferente é descrito para cada um dos 21 tipos de pecador.}

Tabela 1 - Tipos de pecados e seus castigos.

\begin{tabular}{|c|c|c|c|c|}
\hline $\begin{array}{l}\text { Numeração } \\
\text { para facilitar } \\
\text { a referência }\end{array}$ & Condenado (a) & Crime ou pecado cometido & $\begin{array}{l}\text { Castigo infringido e localização no inferno } \\
\text { (quando é mencionado) }\end{array}$ & $\begin{array}{l}\text { Referência no texto } \\
\text { do ApPe }\end{array}$ \\
\hline 1 & Homens e mulheres & Blasfemaram o caminho da justiça. & $\begin{array}{l}\text { Enforcados(as) pela própria língua com } \\
\text { "fogo inextinguível" espalhado sob eles. }\end{array}$ & Cap. 7, linhas 1-3 \\
\hline 2 & $\begin{array}{l}\text { Aqueles que negaram o } \\
\text { caminho da justiça }\end{array}$ & Negaram o caminho da justiça. & $\begin{array}{l}\text { Anjos da punição os castigam e acendem } \\
\text { sobre eles o fogo do seu tormento, numa } \\
\text { cova grande e cheia. }\end{array}$ & Cap. 7, linhas 5-7 \\
\hline 3 & Duas mulheres & $\begin{array}{l}\text { Trançaram os cabelos para induzir } \\
\text { à fornicação e enredar os homens } \\
\text { à perdição }\end{array}$ & $\begin{array}{l}\text { Lançadas na cova pelos anjos da punição, } \\
\text { penduradas pelos cabelos e pescoços. }\end{array}$ & Cap. 7, linhas 8-11 \\
\hline 4 & $\begin{array}{l}\text { Homens que se deitaram } \\
\text { com essas duas mulheres }\end{array}$ & Fornicação & Pendurados pelos órgãos sexuais na cova. & Cap. 7, linhas 12-14 \\
\hline 5 & $\begin{array}{l}\text { Assassinos e seus mandan- } \\
\text { tes e cúmplices }\end{array}$ & Assassinato & $\begin{array}{l}\text { Lançados no fogo e devorados por vermes } \\
\text { e animais peçonhentos em uma outra } \\
\text { cova. Suas vítimas testemunham suas } \\
\text { condenações. }\end{array}$ & $\begin{array}{l}\text { Cap. } 7 \text {, linhas } 15-18 \\
\text { e } 19-21\end{array}$ \\
\hline 6 & Mulheres & Aborto & $\begin{array}{l}\text { Afundadas até o pescoço em um grande } \\
\text { fosso onde caem excrementos, sendo } \\
\text { atingidas por raios que saem dos olhos dos } \\
\text { filhos abortados que choram em outro fosso } \\
\text { em frente a esse. }\end{array}$ & Cap. 8, linhas 4-7 \\
\hline 7 & Homens e mulheres & Infanticídio & $\begin{array}{l}\text { Nus, vendo seus filhos assassinados. Dos } \\
\text { seios das mulheres sai leite coagulado que } \\
\text { se transforma em bestas devoradoras de } \\
\text { carne, as quais os atacam eternamente. }\end{array}$ & Cap. 8, linhas 8-18 \\
\hline 8 & Homens e mulheres & $\begin{array}{l}\text { Perseguidores e traidores dos justos } \\
\text { de Jesus }\end{array}$ & $\begin{array}{l}\text { Lançados por Ezrael num lugar de escuridão, } \\
\text { com metade dos seus corpos em chamas, } \\
\text { castigados por um espírito de cólera, com } \\
\text { um verme devorando suas entranhas. }\end{array}$ & Cap. 9, linhas 1-5 \\
\hline 9 & Homens e mulheres & $\begin{array}{l}\text { Caluniaram e duvidaram da justiça } \\
\text { de Jesus }\end{array}$ & $\begin{array}{l}\text { Devoram as próprias línguas enquanto } \\
\text { são atormentados com ferros em brasa } \\
\text { queimando seus olhos, ao lado dos } \\
\text { anteriores. }\end{array}$ & Cap. 9, linhas 6-8 \\
\hline 10 & Homens e mulheres & $\begin{array}{l}\text { Falso testemunho contra os mártires, } \\
\text { os levando à morte }\end{array}$ & $\begin{array}{l}\text { Tem os lábios cortados, com fogo entrando } \\
\text { em suas bocas e entranhas. }\end{array}$ & Cap. 9, linhas 9-11 \\
\hline 11 & Homens e mulheres ricos & $\begin{array}{l}\text { Confiaram em suas riquezas e } \\
\text { desprezaram órfãos e viúvas }\end{array}$ & $\begin{array}{l}\text { Vestidos com trapos e roupas sujas e } \\
\text { lançados numa coluna de fogo mais } \\
\text { cortante que espadas, numa pedra. }\end{array}$ & Cap. 9, linhas 12-16 \\
\hline 12 & Homens e mulheres & $\begin{array}{l}\text { Emprestaram dinheiro e cobraram } \\
\text { juros }\end{array}$ & Jogados numa cova cheia de sujeiras. & Cap. 10, linhas 1-2 \\
\hline 13 & Homens & Práticas homossexuais & $\begin{array}{l}\text { Conduzidos por demônios a se lançarem } \\
\text { de montanhas altas e subir de novo, } \\
\text { eternamente. }\end{array}$ & Cap. 10, linhas 3-8 \\
\hline 14 & Homens e mulheres & Idolatria & $\begin{array}{l}\text { Presos em cadeias de fogo numa prisão } \\
\text { de muito fogo, junto com os ídolos que } \\
\text { fizeram. }\end{array}$ & Cap. 10, linhas 9-14 \\
\hline 15 & Homens e mulheres & $\begin{array}{l}\text { Abandonaram os mandamentos de } \\
\text { Deus e seguiram as persuasões dos } \\
\text { demônios }\end{array}$ & Queimados no fogo do juízo. & Cap. 10, linhas 15-17 \\
\hline 16 & Homens e mulheres & Não honraram os pais & $\begin{array}{l}\text { Tentam subir um lugar alto, escorregam } \\
\text { e caem numa cova de onde flui fogo } \\
\text { eternamente. }\end{array}$ & Cap. 11, linhas 1-6 \\
\hline 17 & Rapazes jovens e donzelas & $\begin{array}{l}\text { Desobedeceram aos pais e desres- } \\
\text { peitaram pessoas mais velhas }\end{array}$ & $\begin{array}{l}\text { Enforcados e feridos por pássaros devora- } \\
\text { dores de carne. }\end{array}$ & Cap. 11, linhas 7-11 \\
\hline
\end{tabular}


Tabela 1 - Tipos de pecados e seus castigos.

\begin{tabular}{|c|c|c|c|c|}
\hline $\begin{array}{l}\text { Numeração } \\
\text { para facilitar } \\
\text { a referência }\end{array}$ & Condenado (a) & Crime ou pecado cometido & $\begin{array}{l}\text { Castigo infringido e localização no inferno } \\
\text { (quando é mencionado) }\end{array}$ & $\begin{array}{l}\text { Referência no texto } \\
\text { do ApPe }\end{array}$ \\
\hline$\overline{18}$ & Meninas vestidas de luto & $\begin{array}{l}\text { Perderam a virgindade antes do } \\
\text { casamento }\end{array}$ & $\begin{array}{l}\text { Seriamente punidas e suas carnes são } \\
\text { despedaçadas. }\end{array}$ & Cap. 11, linhas 12-15 \\
\hline 19 & Homens e mulheres & $\begin{array}{l}\text { Foram servos que desobedeceram a } \\
\text { seus senhores }\end{array}$ & $\begin{array}{l}\text { Punidos com fogo eterno enquanto devo- } \\
\text { ram as próprias línguas. }\end{array}$ & Cap. 11, linhas 16-18 \\
\hline 20 & $\begin{array}{l}\text { Homens e mulheres surdos } \\
\text { e cegos, vestidos de branco }\end{array}$ & $\begin{array}{l}\text { Amontoados uns sobre os outros e } \\
\text { caídos sobre brasas de fogo }\end{array}$ & $\begin{array}{l}\text { Deram esmolas se achando justos, mas não } \\
\text { buscaram a justiça. (eles passarão por outro } \\
\text { julgamento e os condenados serão lançados } \\
\text { num rio de fogo). }\end{array}$ & Cap. 12, linhas 1- 7 \\
\hline 21 & Homens e mulheres & Feiticeiros & $\begin{array}{l}\text { Pendurados numa roda de fogo e lançados } \\
\text { numa cova de fogo pelo rodopio da roda. }\end{array}$ & Cap. 12, linhas 8-11 \\
\hline
\end{tabular}

Fonte: Elaborado pelo autor (2021).

Como o foco aqui é observar especificamente essas condenações a partir da Teoria do Monstruoso, passa-se imediatamente à leitura da teoria, tendo no horizonte essas imagens descritas. Neste momento, extensas análises das imagens descritas acima serão evitadas, deixando-as para um momento propício, ao fim do texto.

\section{O corpogrotesco e monstruoso: a chave para interpretaçãode visões dos mortoscondenados no inferno}

Em "A cultura popular na Idade Média e no Renascimento - o contexto de François Rebelais", Bakhtin utiliza a expressão "corpo grotesco" para designar um conceito estético peculiar de corpo. Para Bakhtin, a representação do corpo grotesco é popular, festiva e utópica; corpo grotesco é cósmico, não separado do resto do mundo por fronteiras claras. O grotesco dessa representação está nas aberturas e ramificações do corpo: a boca, o nariz, os órgãos inferiores, os seios, o falo e o ventre. Os fenômenos corporais são enfatizados em um corpo que excede seus limites na cópula e gravidez, no nascimento, na agonia da morte, nos gestos de comer, beber e defecar. O corpo nunca está completo: está o tempo todo criando e sendo criado (Bakhtin, 1999). O monstruoso é parte do grotesco. Toma-se então, como aporte teórico da pesquisa, uma proposta de Teoria do Monstruoso a partir de leituras em Jeffrey Cohen. Entende-se essa teoria como essencial para analisar a fonte e alcançar o objetivo de entender como o CP compreendia o modo de lidar com seus mortos e como esse modo de lidar com seus mortos pode ter afetado a construção de suas narrativas de descrição do além.

De fato, o autor propõe ler a cultura como um corpo monstruoso em si mesmo: não íntegro, sem falhas, mas em uma conjunção de pedaços, partes de diferentes origens que se unem formando uma coisa só. Essa é a sua primeira tese sobre o monstro: que seu corpo é cultural. O corpo do monstro representa a cultura enquanto esse corpo incorpora medo, fantasia, desejo e ansiedade e ganha independência. É um deslocamento, significando sempre algo além dele, e existe apenas para ser lido (Cohen, 1996).

Outra característica do monstro nas teses de Cohen é sua capacidade de escapar e retornar, em constantes mutações, em lugares diferentes. Ele defende que os monstros devem ser interpretados na raiz 
das relações sociais e culturais que os geram. Em cada uma das histórias de monstros, o que se recusa a morrer retorna, ligeiramente diferente, para ser lido de novo, contra os movimentos sociais de sua época ou contra um evento específico. A interpretação do monstro é, nas palavras do autor, "tanto um processo quanto uma epifania, um trabalho que deve se contentar com fragmentos" (Cohen, 1996, p. 30).

Esse constante escapar do monstro, defende Cohen, se dá porque ele não se permite catalogar. São híbridos que resistem às tentativas de enquadramento ou classificação ou estruturação sistemática. Nisso reside o seu perigo: o monstro possui sua forma suspensa entre outras formas, pronta a explodir quaisquer tentativas de classificação. Ele aparece em tempos de crise, questionando o sistema e exigindo o que o autor chama de um repensar de fronteiras da normalidade. Diante do monstruoso, a análise científica e racional se desintegra. O monstro questiona o raciocínio binário e exige uma interpretação polifônica (Cohen, 1996).

Cohen afirma que no corpo monstruoso (e através dele) podem ser inscritas quaisquer alteridades, mas que ele nasce de dentro da cultura e sua diferença aparece como cultural, econômica, social e sexual. A formação do corpo monstruoso, defende Cohen, nunca se dá a partir de fora. O corpo do monstro reúne em si combinações de elementos conhecidos da cultura - em especial, alguns que não combinariam ou que se opõem entre si, como, por exemplo, masculino e feminino unidos em um único corpo (Cohen, 1996). Ele argumenta, nesse sentido, que o monstro é criado dentro de uma cultura também para justificar seu extermínio, transformando o ato de destruição da alteridade em ato heroico. Isso se aplica perfeitamente à análise da na fonte deste artigo: ao condenar seus inimigos ao inferno, o Cristianismo Primitivo extermina aqueles que se comportam diferentemente do padrão esperado, transformando-os em monstros de corpos dilacerados nas regiões do submundo.

Ao combinar fatores, a princípio excludentes e opostos entre si, o monstro revela que a diferença é arbitrária e mutável antes de ser essencial e, com isso, o monstro ameaça destruir os membros individuais de uma sociedade ao mesmo tempo em que ameaça todo o aparato cultural sob o qual essa mesma sociedade se fundamenta e que possibilita a existência individual.

Além de sua função no extermínio da alteridade, o monstro tem também uma função de proteção de limites e fronteiras: ultrapassar determinadas barreiras culturais, sexuais e religiosas é correr o risco de ser devorado pelo monstro e até de se tornar monstruoso também. Nesse sentido, o monstro está sempre ligado a práticas proibidas e, portanto, o medo que se sente do monstro revela, ao mesmo tempo, desejo. Ao mesmo tempo em que causa medo, o monstro atrai. Quando não ultrapassa as fronteiras para questionar suas fragilidades, o monstro atrai por existir como alter ego, por gozar de liberdade em sua existência. A fluidez corporal e a ambiguidade entre medo e desejo causados pelo monstro, defende Cohen, garantem que o monstro exercerá sempre "uma perigosa fascinação" (Cohen, 1996, p. 52). O monstro é um ser do intervalo, dos limites, das fronteiras.

Em sua obra "On monsters: an unnatural history of our worst fears" (Sobre monstros: uma história não-natural de nossos piores medos), Asma também disserta sobre a relação de medo e fascínio a respeito dos monstros na sociedade. Segundo ele acredita, a criação dos monstros está ligada às fobias que as pessoas têm. As fobias surgiram como parte do processo evolutivo da humanidade, tornando possível a continuidade da espécie. Ele defende que o ser humano surge no continente africano e o medo de espécies como cobras e aranhas venenosas fez com que os humanos, ao fugirem desses seres perigosos, sobrevivessem. Ele acredita que a criação dos monstros da cultura surgiu mais ou menos de forma semelhante. Ao descrever um experimento com macacos no zoológico Gardens, Darwin percebeu que mesmo após uma primeira experiência de um dos macacos do grupo, que abriu desavisado um cesto com uma cobra viva dentro e fugiu, todos os outros macacos do grupo tiveram a curiosidade de olhar dentro do cesto (Asma, 2009). 
Asma afirma que nos recentes debates sobre ciência cognitiva, os medos de cobras, aranhas e outras criaturas foram apresentados como exemplos de circuitos mentais pré-configurados no cérebro humano. Embora seja uma ideia controversa, o autor defende que um número crescente de teóricos argumenta que os cérebros humanos vêm gravemente ligados a algum conteúdo de crença, como "cobras = ruim". O fato de que as fobias parecem tão resistentes à revisão à luz de novas experiências sugere que elas são sistemas fechados de informação. Mesmo depois que uma pessoa fóbica é informada de que uma cobra não é venenosa ou testemunha a remoção dos dutos de veneno, ela ainda teme lidar com o réptil. A fobia permanece, , como uma peça teimosa de mobília antiquada na arquitetura da mente. Talvez os monstros também façam parte da mente mobiliada; "Como realidades culturais e psicológicas, os monstros parecem certamente não querer ir embora, não importa quanta luz iluminemos em sua direção", defende Asma (Asma, 2009, p. 5).

Elizangela Soares, embora reconheça a dificuldade de definir o que é o monstro, é bastante assertiva ao mencionar Mark Dorrian, que diz que o monstro é um sinal a ser interpretado, mas também possui os sentidos de mostrar, exibir e de alertar, advertir, anunciar. A relação do ser humano com os monstros possui um caráter de horror e atração. Soares defende que o monstruoso pertence à categoria do grotesco e age para "capturar o que fica entre as classificações da linguagem". Assim, os seus excessos, seja por hibridação, deficiência ou distorção de suas partes, pedem por interpretação (Nogueira; Soares, 2019).

Os monstros são criação da cultura para fazer com que as pessoas se questionem, de tempos em tempos, sobre os seus caminhos, escolhas e seus pressupostos culturais sobre raça, gênero, sexo e sua classificação das diferenças. Os monstros "nos perguntam por que os criamos" (Cohen, 1996, p. 55) e essa pergunta é fundamental para esta pesquisa: por que o CP transformou os corpos de condenados ao inferno em corpos grotescos e monstruosos, desmembrados, em suas narrativas de além-mundo?

Segundo afirma Chao (2010), o corpo grotesco deforma e desestabiliza o funcionamento normal da linguagem padrão, fragmentando seu corpo, sua "sintaxe", e destacando suas dimensões metafóricas. Nesse sentido, o corpo grotesco funciona como uma linguagem poética cuja sintaxe é desconectada e cujas metáforas são audaciosas e ambíguas (Chao, 2010). Como eles defendem, o corpo grotesco consiste em diversas partes animadas e/ou inanimadas que são tão misteriosamente justapostas a ponto de tornar o corpo cheio de lacunas imaginativas (Chao, 2010). O grotesco é um corpo no qual partes diversas são misteriosamente combinadas de forma que o espectador tem muita liberdade para criar sua própria resposta às lacunas entre elas. Segundo os autores, o corpo grotesco é metafórico, pois mistura categorias; é uma metáfora que insere no terreno do maravilhoso e que contém um alto grau de contradição ou incongruência óbvia.

Harpham observa que o grotesco invadiu a consciência europeia perto do final do século XV por meio de uma série de escavações em cavernas perto de Roma. Essas escavações revelaram murais que datam da Decadência Romana, nos quais figuras humanas e animais estão entrelaçadas com folhagens de maneiras que violam não apenas as leis da estática e da gravidade, mas também o bom senso e a observação simples. Para o autor, o grotesco é a mais escorregadia das categorias estéticas. Ainda assim, em sua opinião, os murais "grotescos" originais não formam mais o centro da definição do termo e não parecem, mesmo para a maioria das sensibilidades modernas, muito grotescos, gerando o que ele define como uma imagem do grotesco como um órfão estético, vagando de formas em formas, de tempos em tempos (Harpham, 1976).

Por essa razão, uma obra que poderia ter sido considerada grotesca em algum momento, pode perder sua característica com o passar do tempo e à medida em que novas descobertas e tecnologias a normalizam para um determinado público e em determinado momento. 
Tudo isso implica que, ao nos aproximarmos de uma definição do grotesco, nem sempre devemos tomar consistência etimológica por precisão conceitual; a definição desse conceito, quase tão fluida quanto a de beleza, é boa para uma época - mesmo um homem - de cada vez. Ao lidar com o grotesco, ao que parece, deve-se lidar com generalizações grosseiras, arbitrariedade ou afirmações específicas sobre obras específicas. Embora se possa defini-lo em termos das formas empregadas por artistas que, consciente ou inconscientemente (em outras palavras, no julgamento do crítico) usaram o grotesco, ou em termos da psicologia de tal artista, facilmente o mais crucial e mensurável aspecto é o efeito do grotesco no leitor, ouvinte ou espectador. Isso não quer dizer que o gênero de uma obra dependa da credulidade ou do senso de humor do público; é simplesmente reconhecer que, embora as formas do grotesco tenham mudado notavelmente ao longo dos séculos, o complexo emocional denotado pela palavra permaneceu razoavelmente constante (Harpham, 1976, p. 461).

Para Harpham, alguns elementos como animais, vegetações, objetos mecânicos trazidos à vida, entre outros, embora sejam constantemente presentes no grotesco, não são suficientes para defini-lo. Dito de outra maneira, não se pode tentar definir o grotesco por suas formas; o grotesco é uma estrutura: a estrutura do estranhamento. O grotesco deve começar com, ou conter em si, certas convenções estéticas que o leitor sente serem representativas da realidade como ele a conhece. Os temas característicos do grotesco comprometem ou destroem as convenções, abrindo para novas perspectivas vertiginosas caracterizadas pela destruição de lógica e regressão ao inconsciente - loucura, histeria ou pesadelo. Mas essa ameaça depende, para seu êxito, da eficácia do cotidiano, da satisfação parcial das expectativas habituais dos seres humanos. O grotesco depende não apenas das condições físicas cuja deformidade a maioria das pessoas reconheceria, mas também das convenções, preconceitos, lugares-comuns, banalidades e mediocridades de cada um (Harpham, 1976).

Chao (2010) compreende igualmente que nem todas as imagens surreais geram monstros grotescos. Em um sentido amplo, a semente do grotesco está nas imagens em que o real confronta os indivíduos. É uma fase anterior, cujo absurdo auto-aniquilador os motiva ao ato de interpretação que completa a compreensão da imagem (Chao, 2010). Dito de outra forma, para os autores em questão, no grotesco está implícita de forma constante uma disputa entre o que seria visto como fora das convenções e o que se poderia chamar de realidade. As fronteiras, portanto, se desfazem e assim também as formas corporais completas. Ou seja, à medida em que uma ordem se transforma em outra sem limites, aquilo que é determinado, limpo e contínuo torna-se ambíguo, desordenado e fragmentado (Chao, 2010).

De acordo com o entendimento de Harpham, para um objeto ser grotesco, ele deve suscitar as seguintes respostas: riso e espanto, nojo ou horror. Ao pensar no ApPe, por exemplo, imaginar homens pendurados em ganchos pela genitália pode fazer rir, embora não se possa afirmar ser essa a intenção ou proposta da narrativa. Harpham crê que o riso provocado pelo grotesco pode ser uma resposta involuntária a situações que não podem ser tratadas de outra maneira, independentemente da sofisticação do público. Nesses casos, o riso serve para diminuir o horror ou perplexidade e fazer o pesadelo parecer mais suportável. Essa ambiguidade é, em si mesma, central para a resposta ao grotesco, que se abre para um reino de contradição e ambiguidade, frequentemente por meio da fusão de formas ou reinos que se sabe estarem separados. Ainda que o monstruoso seja um braço do grotesco, nem sempre classificações e separações entre monstruoso e risível são possíveis ou mesmo interessantes. O que mais importa aqui é que o grotesco seja compreendido a partir dessa entrada de uma categoria irrompendo dentro da outra, de maneira mais flexível. 


\section{O aspectogrotesco/monstruoso nos corpos desmembrados no inferno}

Para Harpham, uma das formas de utilizar o grotesco como monstruoso é relacionada à feiura e à bestialidade. Isso porque, para o autor, essa característica está clara na cultura ocidental, pelo menos do final do período medieval, quando o pecado, ligado à bestialidade, era comumente retratado em imagens grotescas. A julgar pelo ApPe, pode-se arriscar dizer que elementos grotescos estavam presentes na literatura cristã primitiva muito antes disso, ainda que, do ponto de vista de uma teoria delimitada do grotesco, cair-se-ia em um anacronismo histórico. Por outro lado, não se pode dizer que não sejam grotescas as descrições ali presentes.

Ler os castigos aplicados no inferno no ApPe é se deparar com uma imagem grotesca e monstruosa seguida da outra. Justamente no caráter inacabado de cada uma das punições, de corpos que seguem sendo deformados, esticados, testados em seus limites, queimados, cortados, triturados e devorados eterna e continuamente, como uma morte que não se completa, se encontra o elemento grotesco. Incluindo-se aqui os elementos corpóreos como sangue, excrementos, fluidos corporais diversos e leite materno, tudo isso conduz ao monstruoso porque precisamente no caráter horripilante e inacabado do leite materno se transformando em vermes que não morrem e feras que saem de entranhas, de pássaros devoradores de carne humana, se encontra o monstruoso. Então, o ultrapassar dessas fronteiras reforça a concepção de grotesco-monstruoso.

A criação de monstros por determinada cultura é representativa dessa cultura e parte sempre de dentro dela e nunca de fora, segundo Cohen (1996). É, também, fruto de fobias e medos históricos presentes na mente humana, conforme defende Asma. Para o autor, os monstros da imaginação humana podem ser caricaturas, originalmente construídas sobre ameaças legítimas, mas que acabaram se transformando em elaborações autônomas (Asma, 2009). Freud, em seu ensaio sobre o infamiliar, discute longamente sua escolha por uma espécie de neologismo do alemão para conceber o termo "Das Unheimlich". Ainda que, segundo Freud, o infamiliar seja, em parte, fruto do que os indivíduos recalcam ou proíbem a si mesmos, resumindo de forma bastante superficial, Asma considera o monstruoso como algo que as pessoas temem e pela qual, ao mesmo tempo, são atraídas. Essa dualidade entre a atração e repulsão simultâneas é um aspecto importante da noção a respeito de monstros (Asma, 2009). Segundo ele, o monstro é um conceito flexível e multiuso. Até muito recentemente, aplicava-se às almas infelizes, como de pessoas com algum tipo de limitação física.

\footnotetext{
Durante o século dezenove, 'espetáculos de aberrações' e 'espetáculos monstruosos' eram comuns; essa exploração de pessoas com deficiências genéticas e de desenvolvimento deve ser um dos pontos mais baixos no medidor ético de nossa civilização. Nós nos afastamos desse uso pejorativo particular do monstro, mas ainda empregamos o termo e conceito para aplicar a criaturas desumanas de todas as faixas, mesmo que elas provenham de nossa própria espécie. O conceito do monstro evoluiu para se tornar um termo moral, além de um termo biológico e teológico. Vivemos em uma época, por exemplo, em que a memória recente pode lembrar muitos monstros políticos sádicos (Asma, 2009, p. 8).
}

O termo monstro é frequentemente aplicado a seres humanos que, por suas próprias ações terríveis, abdicaram de sua humanidade. Para Asma, a humanidade é de fato um manto frágil, que pode ser corrompido por forças internas e externas a si mesma e, por isso mesmo, todo mundo tem o potencial de se tornar monstruoso. Um aspecto do conceito de monstro parece ser o colapso da inteligibilidade. Uma ação ou uma pessoa ou uma coisa é monstruosa quando não pode ser processada pela racionalidade 
humana e também quando não é possível se relacionar prontamente com o alcance emocional envolvido. As pessoas sabem o que é odiar, por exemplo, mas quando designam um ódio monstruoso, estão reconhecendo que tal sentimento está fora do seu entendimento. Nesse sentido, especialmente a respeito de seres humanos descritos como monstruosos, aplica-se uma designação moral que depende, em muitos aspectos, de pontos de vista. Por esse viés, segundo o autor, uma pessoa é demonizada ou transformada em monstro por pessoas que se beneficiam da rotulagem depreciativa. Monstros são "construídos" e servem como bodes expiatórios para agendas convenientes. Esse ponto é importante quando se pensa no ApPe, e nas figuras humanas dos condenados ali depreciados, demonizados e considerados monstruosos a partir da retórica depreciativa do cristianismo primitivo para com seus opositores.

Segundo Asma, ser um monstro é ser um presságio. Às vezes o monstro é uma demonstração da ira de Deus, um presságio do futuro, um símbolo de virtude moral ou vício, ou um acidente da natureza. O monstro é mais que uma criatura odiosa da imaginação; é uma espécie de categoria cultural, empregada em domínios tão diversos quanto religião, biologia, literatura e política. O autor afirma que desconfia que os monstros sejam arquétipos metafóricos de natureza pré-linguística do pensamento humano, moldados por convenções culturais e tendências psicofísicas nativas. Ou seja, de mãos dadas com a ideia de que as metáforas moldam o pensamento, a comunicação e até mesmo o sentimento (Johnson; Lakoff, 1980), está a ideia de que a imaginação é mais ativa na imagem da realidade do que se reconhecia anteriormente. O monstro, é claro, é um produto e um habitante regular da imaginação, mas a imaginação é uma força motriz por trás de toda a percepção humana a respeito do mundo. Para o autor, "se encontramos monstros em nosso mundo, às vezes é porque eles estão realmente lá e às vezes porque os trouxemos conosco" (Asma, 2009, p. 9).

Sobre o uso da palavra "monstro", Asma acredita que, devido a inúmeras utilizações pejorativas e preconceituosas ao longo da história, dificilmente em algum momento da história humana será possível utilizar a palavra "monstro" como descritiva apenas; sem atribuição de algum juízo de valor. Quando traduzem o termo "Das Unheimliche" utilizado por Freud para infamiliar, Hernani Chaves e Pedro Tavares assumem as dificuldades de sua tradução e optam por "infamiliar" por entenderem que o prefixo "in" traria a experiência mais próxima da negação que o prefixo alemão "Un" também representa. Independentemente dessa tradução, o que Freud parece pretender com o neologismo que cria em "Das Unheimlich" é atentar para o aspecto aterrorizante daquilo que é, por um lado, o contrário do familiar e que pode ser reconhecido, mas que é também um aspecto de algo que deveria permanecer oculto, mas veio à tona (Freud, 1919). Nesse sentido, o conceito de "infamiliar" em Freud se aproxima do nosso "monstruoso":

Em muitas pessoas, o mais elevado grau do infamiliar aparece associado à morte, a cadáveres e ao retorno dos mortos, a espíritos e fantasmas. Já ouvimos que em muitas línguas existe a expressão 'uma casa infamiliar', cujo significado não nos poderia ser restituído a não ser reformulando-o: uma casa mal-assombrada. Poderíamos, de fato, ter começado nossa investigação talvez pelo mais forte exemplo da infamiliaridade, mas não o fizemos, porque aqui o infamiliar se mescla bastante com o horrorífico e, em parte, é por ele recoberto. Mas raramente em algum outro domínio nossos pensamentos e sentimentos mudaram tão pouco desde os tempos primitivos - o antigo permaneceu tão bem escondido sob uma fina coberta - quanto na nossa relação com a morte. Dois fatores nos informam bem sobre esse silêncio: a força de nossas reações emocionais originárias e a incerteza de nosso conhecimento científico (Freud, 1919, p. 73).

Ainda em sua jornada para buscar esclarecer o conceito de infamiliar no campo psíquico humano, Freud discute também o infamiliar que surge dos complexos infantis e especialmente na ficção, na criação 
literária². Esse é um dos pontos que mais merece a atenção do autor e, sobretudo, que mais interessa ao tema deste artigo. Segundo Freud, o infamiliar da criação literária é muito mais rico porque abrange a totalidade, pois não aparece sob as condições das experiências vividas. Ou seja,

[...] o reino da fantasia tem como pressuposto de sua legitimação o fato de que seu conteúdo foi dispensado da prova de realidade. O resultado paradoxal que ressoa aqui é que na criação literária não é infamiliar muito daquilo que o seria se ocorresse na vida e que na criação literária existem muitas possibilidades de atingir efeitos do infamiliar que não se aplicam à vida (Freud, 1919, p. 79).

O autor explica que dentre as muitas liberdades do escritor, há também aquela de poder escolher, de acordo com sua preferência, seu modo de figurar o mundo, seja fazendo-o concordar com a realidade conhecida ou seja, de certo modo, afastando-se dela. De toda forma, aqui ele é seguido. Nesse sentido, o mundo da literatura pode relativizar o que Freud chama de infamiliar: no reino da ficção, muita coisa que seria infamiliar, caso sucedesse na vida, ali não o é. Os leitores e/ou interlocutores ajustam seu juízo às condições dessa realidade fingida pelo escritor e tratam as almas, os espíritos e os fantasmas como se tivessem uma existência justificada, assim como na realidade material. Também nesse caso a infamiliaridade está ausente.

Mas Freud reconhece que o escritor tem o poder de tornar a coisa diferente quando procura iludir seus leitores e se coloca, aparentemente, no interior da realidade comum. Nesse caso, ele assume também todas as condições que são válidas, nas vivências, para o surgimento do infamiliar, e tudo aquilo que, na vida, tem efeito infamiliar também o tem na criação literária. Mas, nesse caso, o escritor pode elevar e diversificar esse infamiliar bem além daquilo que é possível nas vivências, na medida em que ele deixa acontecer aquilo que, na realidade, raramente ou nunca chega a se tornar experiência. Em certa medida, diz Freud (1919, p. 82): "ele (o escritor) trai as crenças que supúnhamos superadas, ele nos ilude, na medida em que nos promete a realidade comum, quando, de fato, vai muito além dela".

\section{Conclusão}

Este artigo propõe uma leitura da fonte utilizada, o ApPe, à luz da Teoria do Monstruoso. Como foi dito até aqui, é extremante difícil enquadrar o monstruoso em uma única categoria ou catálogo fechado. Isso iria contra o monstruoso em si. O que talvez se aproxime de uma definição de monstruoso é a não-definição, o seu alargamento e seus desdobramentos de tempos em tempos. Como os autores aqui citados defendem, o que fez determinada cultura temer, sentir nojo ou até mesmo rir pode não surtir mais o mesmo efeito em outro momento, para outro grupo que recebe determinado objeto ou narrativa. Não é sobre o efeito alcançado que reside o monstruoso. O grotesco-monstruoso reside nesse aspecto híbrido que não se deixa capturar, que foge das definições e prisões interpretativas. É o elemento que, na cultura, ora impressiona e faz temer, ora fascina. Esteve presente no passado e está presente hoje. Faz parte da constituição do ser humano, de seus medos e fascínios mais escondidos e que, vez ou outra, seja por forças externas ou internas, vem à tona e o obriga a lidar com eles.

O monstruoso se esconde e reaparece na cultura, em governos autoritários, em Jesus-Messias armados, destrutivos de alteridades e, por isso, monstruosos. Por essa razão, defende-se aqui que textos como o Apocalipse de Pedro possuem um forte caráter monstruoso. Reside no desejo de ver corpos sendo destroçados, aniquilados, manipulados; o aspecto monstruoso da destruição e, ao mesmo tempo, da

\footnotetext{
2 Para uma breve distinção entre ficção literária e textos religiosos, retomar a discussão sobre o tema a partir da obra de Alter (2007).
} 
sobrevivência para que o sofrimento não se esgote. Os textos apocalípticos, sobretudo os que descrevem o inferno, possuem esse caráter violento e híbrido tão presente no monstruoso. Talvez seja mesmo muito difícil estabelecer um padrão ou ordenamento para todos os relatos de inferno e castigos que dão sequência às narrativas do ApPe. Se, como discutiu-se nos primeiros séculos, a obra tivesse entrado no cânon, hoje se poderia ter um padrão estabelecido de inferno. Não foi o que aconteceu. O que existe são sequências, mais ou menos violentas, que reproduzem, mas também selecionam elementos específicos de descrição de castigos e destruições. O monstruoso reside também nesse aspecto: os monstros, os condenados, os infernos e suas penas não se deixam capturar, não se deixam catalogar, não se permitem limitar.

\section{Referências}

Alter, R. A arte da narrativa bíblica. São Paulo: Companhia das Letras, 2007.

Asma, S. On Monsters: an Unnatural History of our worst fears. New York: Oxford University Press, 2009.

Bakhtin, M. A cultura popular na idade média e no renascimento: o contexto de François Rabelais. 4. ed. São Paulo: Hucitec, 1999.

Bauckham, R. The Fate of the dead: studies on the jewish and Christians Apocalypses. Boston: Brill, 1998.

Chao, S.-L. Rethinking the concept of the grotesque: Crashaw; Baudelaire; Magrite. London: Legenda. 2010. (Studies in Comparative Literature, n. 22).

Cohen, J. J. (ed.). Monster theory: reading culture. London: University of Minnesota Press, 1996.

Elliott, J. K. Apocryphal new testament. Oxford: Clarendon Press, 1993.

Freud, S. O Infamiliar: [Das Unheimliche]. Tradução: Ernani Chaves e Pedro Heliodoro Tavares. São Paulo: Autêntica Editora, 1919.

Harpham, G. The Grotesque: first principles. The Journal of Aesthetics and Art Criticism, v. 34, n. 4, p. 461-468, 1976.

Iser, W. The reality of fiction: a functionalist approach to literature. New Literary History, v. 7, n. 1, p 7-38, 1975.

Johnson, M.; Lakoff, G. Metaphors we live by. Chicago: University of Chicago Press, 1980.

Nogueira, P. A. S. Introdução. In: Nogueira, P. A. S. (org.). O imaginário de além-mundo na apocalíptica e na literatura visionária medieval. São Bernardo do Campo: Universidade Metodista de São Paulo, 2015.

Nogueira, P. A. S.; Soares, E. A. Exegese nos limites do sentido: os métodos histórico críticos e as formas do monstruoso. Estudos Teológicos, v. 59, n. 2. p. 423-427, 2019.

Schneemelcher, W. New Testament Apocrypha. Writings relating to the apostles: Apocalypses and related subjects. Lousville \& Kentucky: Westminster John Knox Press, 2003. v. 2.

Como citar este artigo/How to cite this article

Mattos, C. E. A. Imagens grotescas de corpo no Apocalipse de Pedro. Reflexão, v. 46, e215532, 2021. https://doi. org/10.24220/2447-6803v46e2021a5532 